Konya Mühendislik Bilimleri Dergisi, c. 9, s. 4, 889-903, 2021

Konya Journal of Engineering Sciences, v. 9, n. 4, 989-903, 2021

ISSN: 2667-8055 (Elektronik)

DOI: 10.36306/konjes.946496

\title{
METAHEURISTIC ALGORITHMS BASED APPROACHES FOR EFFICIENCY ANALYSIS OF THREE-PHASE DRY-TYPE TRANSFORMERS
}

\author{
${ }^{1}$ Seda KUL (D) , 2 Seyit Alperen CELTEK (D) , 3 Ires ISKENDER \\ ${ }^{1}$ sedakul@kmu.edu.tr, ${ }^{2}$ salperenceltek@kmu.edu.tr, ${ }^{3}$ ires@cankaya.edu.tr \\ ${ }^{1}$ Karamanoglu Mehmetbey University, Engineering Faculty, Electrical Electronics Engineering Department, \\ Karaman, TURKEY \\ ${ }^{2}$ Karamanoglu Mehmetbey University, Engineering Faculty, Energy Engineering Department, Karaman, \\ TURKEY \\ ${ }^{3}$ Cankaya University, Engineering Faculty, Electrical Electronics Engineering Department, Ankara, TURKEY
}

(Geliş/Received: 01.06.2021; Kabul/Accepted in Revised Form: 07.09.2021)

\begin{abstract}
Transformers are considered as the significant contributors to the efficient transmission and distribution of electrical energy. The ability to change the voltage and current levels in inverse proportion help to reduce the conductor losses. However, today's stringent requirements for more significant efficiency markings turn attention to the efficiency of individual components in a power system. Therefore, a great deal of effort is being placed to maximize the efficiency of the transformers without compromising their fundamental function. This is a complex problem and requires the use of advanced design tools. Metaheuristic methods developed in recent years are being used in electrical engineering, where they provide savings in design time and great success in finding the optimum solution. In this study, we have used the Particle Swarm Optimization (PSO), the Simulated Annealing (SA), and the Tree Seed Algorithm (TSA) methods, respectively. The objective is to develop a design methodology for threephase dry-type transformers and to maximize their efficiency. The results of the three algorithms are compared to validate the optimum solution. For the demonstration of the process, a three-phase $100 \mathrm{kVA}$ dry-type transformer is used. After the mathematical model of the transformer is created, the transformer parameters, current density (s), and transformer iron cross-section acceptability (C) are optimized. As a result, it has been observed that the efficiency of transformers can be increased beyond what is achieved with conventional techniques. The efficiency has been optimized and increased from $97.5 \%$ to $98.44 \%$.
\end{abstract}

Key Words: Optimization, dry-type transformer, metaheuristic algorithms, transformer efficiency.

\section{Üç Fazlı Kuru Tip Transformatör Verimliliği İçin Meta Sezgisel Algoritma Tabanlı Yaklaşımlar}

ÖZ: Transformatörler, elektrik enerjisinin verimli iletimi ve dağıtımına önemli katkı sağlayan unsurlar olarak kabul edilir. Gerilim ve akım seviyelerini ters orantılı olarak değiştirme yeteneği, iletken kayıplarının azaltılmasına yardımcı olur. Bununla birlikte, günümüzün daha önemli verimlilik işaretlerine yönelik katı gereksinimleri, bir güç sistemindeki bireysel bileşenlerin verimliliğine dikkat çekiyor. Bu nedenle, temel işlevlerinden ödün vermeden transformatörlerin verimliliğini en üst düzeye çıkarmak için büyük çaba sarf edilmektedir. Bu karmaşık bir sorundur ve gelişmiş tasarım araçlarının kullanılmasını gerektirir. Son yıllarda geliştirilen meta-sezgisel yöntemler, tasarım süresinde tasarruf ve optimum çözümü bulmada büyük başarı sağladıklarından elektrik mühendisliğinde kullanılmaktadır. Bu çalışmada sırasıyla Parçacık Sürü Optimizasyonu (PSO), Benzetimli Tavlama (SA) ve Ağaç Tohum Algoritması (TSA) yöntemlerini kullandık. Amaç, üç fazlı kuru tip transformatörler için bir tasarım metodolojisi geliştirmek ve verimliliklerini en üst düzeye çıkarmaktır. Üç algoritmanın sonuçları, optimum çözümü doğrulamak için karşılaştırılır. Prosessin gösterimi için üç fazlı $100 \mathrm{kVA}$ kuru tip bir 
transformatör kullanılır. Transformatörün matematiksel modeli oluşturulduktan sonra transformatör parametreleri, akım yoğunluğu (s) ve transformatör demir kesiti kabul edilebilirliği (C) optimize edilmiştir. Sonuç olarak, transformatörlerin verimlerinin geleneksel tekniklerle elde edilenin üzerinde artırılabileceği gözlemlenmiştir. Verimlilik optimize edilmiş ve 0.975 'ten 0.9844 'e yükseltilmiştir.

Anahtar Kelimeler: Optimizasyon, kuru tip transformatör, meta sezgisel algoritmalar, transformatör verimliliği.

\section{INTRODUCTION}

In recent years, increasing demand for eco-friendly and efficient energy systems has made dry-type transformers the top choice of many critical applications. The main motivation behind this choice is that the dry-type transformers are safer and more reliable compared to oil-immersed transformers. They are the ideal choices for risky areas, industrial plants, environments that require safety, reliability, nonflammable, and eco-friendly such as marine systems, transit applications, and urban areas. However, this type of transformer is more expensive and has voltage and power limitations. Therefore, the critical problem in overall design has become achieving an optimal solution for cost and efficiency. Many techniques have been developed and applied to reduce the cost and improve the efficiency of the dry-type transformers. In literature, optimum design of dry-type transformers has been studied using different optimization techniques such as Genetic Algorithm (GA), Artificial Bee Colony (ABC), Particle Swarm Optimization (PSO), Artificial Neural Network (ANN), and different nature-inspired and metaheuristic algorithms.

In this section, an overview of the optimization studies of transformers is presented. These studies have used different optimization techniques and considered optimizing the cost, mass, efficiency, parameter, and temperature. The minimum cost and mass optimization analysis for a $1.5 \mathrm{kVA}$ dry-type transformer was performed using the GA with two different mutation operators and compared against each other (Celebi, 2008). The genetic algorithm is one of the oldest known optimization methods for transformer design. In (Smolka and Nowak, 2011), the GA and the Computational Fluid Dynamics (CFD) were used to optimize the coil and air-gap dimensions for hot-spot and average temperature. These results are compared with the existing devices. After the GA applications, the researcher in (Tosun et al., 2012) used the Tabu Search Algorithm to obtain the minimum weight for the maximum efficiency. They compare this method with the classic numerical calculation results for a $1.5 \mathrm{kVA}$ three-phase transformer in terms of efficiency.

Cost is an essential parameter during the design process in industry; therefore, mass optimization is a popular topic for studying; however, efficiency and dimension validation should be considered in terms of feasibility. The general objective of the studies is cost optimization with different techniques and evaluating the performance by comparing the results against each other (Cheema et al., 2013; Azizian et al., 2016; Patil and Kushare, 2016; Orosz et al., 2017; Gaikwad, 2018). (Cheema et al., 2013) uses four different methods for comparing and examining the result in terms of efficient thermal design. GA and SA were used to optimize the overall cost of the system for the real data of all types of transformers, such as oilimmersed and dry-type in (Gaikwad, 2018). Then, GA, PSO, and ABC are also compared according to performance and process speed (Azizian et al., 2016). The Grey Wolf optimization technique was implemented for the first time in transformer optimization and compared to other optimization methods in (Orosz et al., 2017). Invasive Weed optimization was first time used in an industrial application with other metaheuristic methods (Aksu and Demirdelen, 2018). Another study used the Tree Pruning method for design optimization; a 200 MVA transformer was simulated with FEM (Soldoozy et al., 2018). Researchers optimized all design parameters in order to minimize both the losses and the cost. In (Demirdelen, 2018), the volume optimization and minimum-cost maximum efficiency optimization were performed using the Firefly algorithm (FA). It was used for the first time in volume calculation in this study. The PSO algorithm was used to decide the joint design of the transformer based on core performance, and a FEM model was created based on obtained parameters (Alyozbaky et al., 2019). 
In other studies, up to now, they mainly used optimization algorithms such as Genetic Algorithm, ANN, surface respond, pattern search, honey bee mating, ant colony optimization for cost, thermal, loss, and mass optimization and compared their performances. Later, some tested their suitability with FEM, and some made measurements on existing transformers (Zhang et al., 2013; Orosz et al., 2020). All the literature review made in this paper is summarized in Table 1. It is seen that the efficiency analysis of transformers is the fundamental subject almost in every design optimization; what comes later is the optimization of cost, weight, volume, and thermal behavior, respectively.

Table 1. Review summary of fundamental optimization studies made for transformers

\begin{tabular}{|c|c|c|c|c|c|c|}
\hline Ref. & Year & $\begin{array}{l}\text { Cooling } \\
\text { Type }\end{array}$ & $\begin{array}{l}\text { Objective } \\
\text { Function }\end{array}$ & $\begin{array}{l}\text { Optimization } \\
\text { Technique }\end{array}$ & Methodology & Conclusion \\
\hline (Celebi, 2008) & 2008 & $\begin{array}{l}\text { Dry- } \\
\text { type }\end{array}$ & $\begin{array}{l}\text { Min-cost } \\
\text { and mass }\end{array}$ & $\begin{array}{c}\text { Genetic } \\
\text { Algorithm }\end{array}$ & $\begin{array}{l}\text { Optimized } C \text { and } s \\
\text { parameters with two } \\
\text { different mutation } \\
\text { operators }\end{array}$ & $\begin{array}{l}\text { Random and partial mutation } \\
\text { operators are applied, and } \\
\text { random mutation yields a } \\
\text { better performance to get the } \\
\text { minimum mass }\end{array}$ \\
\hline $\begin{array}{l}\text { (Tosun et al., } \\
\text { 2012) }\end{array}$ & 2012 & $\begin{array}{l}\text { Dry- } \\
\text { type }\end{array}$ & Min weight & $\begin{array}{l}\text { Tabu Search } \\
\text { Algorithm }\end{array}$ & $\begin{array}{c}\text { Numeric Transformer } \\
\text { formulation }\end{array}$ & $\begin{array}{l}\text { Comparing mathematical and } \\
\text { optimization results within } \\
\text { each other }\end{array}$ \\
\hline $\begin{array}{l}\text { (Cheema et } \\
\text { al., 2013) }\end{array}$ & 2013 & Oil-type, & Min cost & $\begin{array}{l}\text { Direct search, } \\
\text { Differential } \\
\text { Evolution, } \\
\text { Simulated } \\
\text { annealing, } \\
\text { Random } \\
\text { search, }\end{array}$ & $\begin{array}{l}\text { The hybrid approach is } \\
\text { composed of multiple } \\
\text { algorithms constrained } \\
\text { optimization of the } \\
\text { objective function. Four } \\
\text { differently rated } \\
\text { transformers were } \\
\text { designed and tested. }\end{array}$ & $\begin{array}{l}\text { Design made by this } \\
\text { optimization achieves lower } \\
\text { magnetic flux density and } \\
\text { current density. Optimization } \\
\text { results have improved } \\
\text { efficiency, and projected } \\
\text { longer operational lifetimes, } \\
\text { and so on. }\end{array}$ \\
\hline $\begin{array}{l}\text { (Azizian et } \\
\text { al., 2016) }\end{array}$ & 2016 & $\begin{array}{l}\text { Dry- } \\
\text { type }\end{array}$ & Min cost & $\begin{array}{l}\text { GA, PSO, } \\
\text { ABC }\end{array}$ & $\begin{array}{l}\text { Compared within each } \\
\text { other in terms of } \\
\text { design parameters and } \\
\text { cost }\end{array}$ & $\begin{array}{l}\text { PSO is the best in terms of } \\
\text { rapid convergence, accuracy, } \\
\text { and simplicity of } \\
\text { implementation }\end{array}$ \\
\hline $\begin{array}{l}\text { (Patil and } \\
\text { Kushare, } \\
\text { 2016) }\end{array}$ & 2016 & $\begin{array}{l}\text { Dry- } \\
\text { type }\end{array}$ & $\begin{array}{l}\text { low cost, } \\
\text { low weight, } \\
\text { small size }\end{array}$ & FEM & $\begin{array}{c}\text { Optimized value of } \\
\text { Inter-coil spacing or } \\
\text { the insulation thickness }\end{array}$ & $\begin{array}{l}\text { Analysis of the Electric field } \\
\text { stresses three variants of Inter- } \\
\text { coil insulation thickness using } \\
\text { FEM by ElecNet software. }\end{array}$ \\
\hline $\begin{array}{c}\text { (Orosz et al., } \\
\text { 2017) }\end{array}$ & 2017 & $\begin{array}{l}\text { Dry- } \\
\text { type }\end{array}$ & Min cost & $\begin{array}{c}\text { Meta } \\
\text { Heuristic, } \\
\text { Brute Force } \\
\text { Algorithm, } \\
\text { PSO, Gray } \\
\text { wolf } \\
\text { optimization, }\end{array}$ & $\begin{array}{l}\text { These four techniques } \\
\text { were compared to see } \\
\text { the accurate solution in } \\
\text { the case of core-form } \\
\text { power transformers. }\end{array}$ & $\begin{array}{l}\text { The meta-heuristic algorithm } \\
\text { gave more accurate results in } \\
\text { a much shorter time than any } \\
\text { other examined method. The } \\
\text { grey wolf optimization } \\
\text { algorithm had a better } \\
\text { performance for low iterations } \\
\text { than the particle swarm } \\
\text { optimization. }\end{array}$ \\
\hline (Basak, 2017) & 2017 & $\begin{array}{l}\text { Dry- } \\
\text { type }\end{array}$ & Min cost & $\begin{array}{c}\text { Simulated } \\
\text { Annealing } \\
\text { and Pattern } \\
\text { Search } \\
\end{array}$ & $\begin{array}{c}\text { Finding optimal design } \\
\text { parameters for low cost } \\
\text { using effective } \\
\text { methods }\end{array}$ & $\begin{array}{c}\text { SA has better optimal design } \\
\text { parameters result for min-cost } \\
\text { than a pattern search } \\
\text { algorithm }\end{array}$ \\
\hline $\begin{array}{l}\text { (Gaikwad, } \\
\text { 2018) }\end{array}$ & 2015 & $\begin{array}{l}\text { Oil-type, } \\
\text { synthetic } \\
\text { oil-type } \\
\text { and Dry- } \\
\text { type }\end{array}$ & Min cost & $\begin{array}{c}\text { GA and } \\
\text { Simulated } \\
\text { Annealing }\end{array}$ & $\begin{array}{c}\text { Insurance cost is } \\
\text { optimized using GA to } \\
\text { achieve economic } \\
\text { benefits and optimal } \\
\text { placement }\end{array}$ & $\begin{array}{c}\text { The working model } \\
\text { optimized placing, rating, } \\
\text { quantity considering average } \\
\text { demand and gave a user- } \\
\text { friendly tool, optimize placing } \\
\text { for } \\
\text { getting cost-effective results in } \\
\text { terms of different types of } \\
\text { transformers. }\end{array}$ \\
\hline $\begin{array}{l}\text { (Aksu and } \\
\text { Demirdelen, } \\
\text { 2018) } \\
\end{array}$ & 2018 & $\begin{array}{l}\text { Dry- } \\
\text { type }\end{array}$ & $\begin{array}{l}\text { Min weight } \\
\text { and cost, } \\
\text { max }\end{array}$ & $\begin{array}{c}\text { Firefly, } \\
\text { Invasive } \\
\text { Weed, Multi- }\end{array}$ & $\begin{array}{c}C \text { and } s \text { parameters are } \\
\text { optimized }\end{array}$ & $\begin{array}{l}\text { PSO finds the fastest way to } \\
\text { the optimal solution. FA } \\
\text { algorithm calculated weight }\end{array}$ \\
\hline
\end{tabular}




\begin{tabular}{|c|c|c|c|c|c|c|}
\hline & & & efficiency & $\begin{array}{l}\text { Objective } \\
\text { Algorithms }\end{array}$ & & $\begin{array}{l}\text { priority; the IWO algorithm } \\
\text { calculated weight and } \\
\text { efficiency with the same } \\
\text { priority. }\end{array}$ \\
\hline $\begin{array}{l}\text { (Soldoozy et } \\
\text { al., 2018) }\end{array}$ & 2018 & Oil- type & $\begin{array}{l}\text { Min weight } \\
\text { and cost, } \\
\text { design } \\
\text { optimization }\end{array}$ & $\begin{array}{l}\text { Tree Pruning } \\
\text { Method }\end{array}$ & $\begin{array}{c}\text { Genetic algorithm, } \\
\text { unrestricted } \\
\text { population size } \\
\text { evolutionary multi- } \\
\text { objective optimization, } \\
\text { and heuristic method } \\
\text { were compared. }\end{array}$ & $\begin{array}{c}6.5 \%, 5.9 \% \text { and } 2.1 \% \text { reduced, } \\
\text { respectively. }\end{array}$ \\
\hline $\begin{array}{c}\text { (Demirdelen, } \\
\text { 2018) }\end{array}$ & 2018 & Oil type & $\begin{array}{c}\text { Volume } \\
\text { optimization }\end{array}$ & $\begin{array}{c}\text { Firefly } \\
\text { optimization }\end{array}$ & $\begin{array}{l}\text { Optimization of design } \\
\text { parameters of } \\
\text { transformer and } \\
\text { comparison with GA } \\
\text { results } \\
\end{array}$ & $\begin{array}{l}\text { Obtained results with FA were } \\
\text { better than those obtained } \\
\text { with GA. FA was also faster. }\end{array}$ \\
\hline $\begin{array}{c}\text { (Alyozbaky et } \\
\text { al., 2019) }\end{array}$ & 2019 & Oil-type & Min loss & $\mathrm{PSO}$ & $\begin{array}{l}\text { Different joint types } \\
\text { and materials were } \\
\text { used to obtain the } \\
\text { optimal design } \\
\text { parameter. }\end{array}$ & $\begin{array}{l}\text { An interaction was observed } \\
\text { between Matlab code for PSO } \\
\text { and the ANSYS software. The } \\
\text { first results generated by the } \\
\text { PSO were used. The losses, } \\
\text { core, and oil temperature were } \\
\text { measured using the ANSYS } \\
\text { software. }\end{array}$ \\
\hline $\begin{array}{c}\text { (Demirdelen, } \\
\text { 2019) }\end{array}$ & 2019 & $\begin{array}{l}\text { Dry- } \\
\text { type }\end{array}$ & $\begin{array}{l}\text { Optimum } \\
\text { efficiency }\end{array}$ & $\begin{array}{c}\text { Firefly } \\
\text { optimization }\end{array}$ & $\begin{array}{l}\text { Optimum efficiency } \\
\text { was evaluated } \\
\text { depending on the } \\
\text { losses, winding size, } \\
\text { and the } C \text { coefficient. } \\
\text { Magnetic and thermal } \\
\text { analysis concerning the } \\
\text { lifetime of the } \\
\text { transformer were done }\end{array}$ & $\begin{array}{c}\text { Single Phase Transformer was } \\
\text { designed and optimized based } \\
\text { on design parameters, and the } \\
\text { result showed that optimal } \\
\text { efficiency has a significant } \\
\text { impact on the temperature } \\
\text { behavior }\end{array}$ \\
\hline $\begin{array}{l}\text { (Rodríguez, et } \\
\text { al., 2019) }\end{array}$ & 2019 & $\begin{array}{l}\text { Dry- } \\
\text { type }\end{array}$ & $\begin{array}{l}\text { Geometric } \\
\text { parameters } \\
\text { were } \\
\text { optimized to } \\
\text { reduce } \\
\text { power loss }\end{array}$ & $\begin{array}{l}\text { Artificial Bee } \\
\text { algorithm }\end{array}$ & $\begin{array}{l}\text { Power loss and volume } \\
\text { were optimized to get } \\
\text { min cost }\end{array}$ & $\begin{array}{l}\text { Six design parameters were } \\
\text { optimized and compared with } \\
\text { ABC, ant colony, honey bee } \\
\text { mating, simulated annealing } \\
\text { optimization algorithms }\end{array}$ \\
\hline $\begin{array}{l}\text { (Esenboga } \\
\text { and } \\
\text { Demirdelen, } \\
\text { 2020) }\end{array}$ & 2020 & $\begin{array}{l}\text { Dry- } \\
\text { type }\end{array}$ & $\begin{array}{l}\text { Min weight } \\
\text { and cost, } \\
\text { max } \\
\text { efficiency }\end{array}$ & $\begin{array}{c}\text { PSO based on } \\
\text { ANN }\end{array}$ & $\begin{array}{c}C \text { and } s \text { parameters are } \\
\text { optimized }\end{array}$ & $\begin{array}{c}\text { Weight and efficiency values } \\
\text { were obtained, and FEM } \\
\text { analysis }\end{array}$ \\
\hline $\begin{array}{l}\text { (Wang et al., } \\
\text { 2020) }\end{array}$ & 2020 & $\begin{array}{l}\text { Dry- } \\
\text { type }\end{array}$ & $\begin{array}{l}\text { Min loss } \\
\text { and cost }\end{array}$ & GA & $\begin{array}{l}\text { The cross-sectional } \\
\text { area of the core and } \\
\text { length of the winding } \\
\text { coil are optimized to } \\
\text { minimize loss and cost }\end{array}$ & $\begin{array}{l}\text { The relationship between loss, } \\
\text { cost, and design parameters } \\
\text { was analyzed, an optimization } \\
\text { model was established with } \\
\text { min loss and cost optimization } \\
\text { aim. }\end{array}$ \\
\hline $\begin{array}{l}\text { (Orosz et al., } \\
\text { 2020) }\end{array}$ & 2020 & $\begin{array}{l}\text { Oil- } \\
\text { immerse } \\
\mathrm{d}\end{array}$ & $\begin{array}{l}\text { Min total } \\
\text { cost }\end{array}$ & $\begin{array}{l}\text { NSGA II and } \\
\text { FEM }\end{array}$ & $\begin{array}{l}\text { The study presents a } \\
\text { novel, evolutionary } \\
\text { algorithm-based } \\
\text { transformer } \\
\text { optimization to } \\
\text { determine the optimal } \\
\text { conductor shape for } \\
\text { the windings during } \\
\text { this examined design } \\
\text { stage. }\end{array}$ & $\begin{array}{l}\text { The precision of the analytical } \\
\text { formulas used is about } 5 \% \text { less } \\
\text { compared to FEM-based } \\
\text { calculations. This difference is } \\
\text { acceptable as less than } 1 \% \text {. }\end{array}$ \\
\hline
\end{tabular}

In this paper, the optimization problem is defined mathematically by expressing the objective function in terms of the analytical formulas used by manufacturers for the electromagnetic design of transformers. 
We have come across many brand-new research and publications that propose novel metaheuristic algorithms for optimization during our literature review study so far. Our motivation is to quickly adopt this technology to our field of expertise and improve dry-type transformers. Verified performance via Finite Element Analysis (FEA) and computer simulation will guide designers and accelerate the design of future high-performance transformers. Therefore, in this study, the Tree Seed Algorithm (TSA) optimization method, which is a newly developed optimization algorithm, is used in dry-type transformer optimization for the first time. The results are compared with other metaheuristics techniques for performance verification.

Finite Element Analysis of the transformer has been simulated using the optimized design parameters for electromagnetic behavior to validate the result. This application allows us to test the optimization results faster. If the results do not match the practical application, optimization can be repeated.

It is possible to summarize the main objectives of this study as follows:

- First time application of the Tree Seed Algorithm to a dry-type transformer design optimization problem

- Comparing results in terms of accuracy, process speed, and performance with other state-of-the-art transformer optimization methods

- Analysis of the transformer via FEM for the validation of optimization results

The rest of the paper is organized as follows. Section 2 describes the mathematical design of a three-phase dry-type transformer. The methodology of the optimization technique and objective functions have been explained in Section 3. The optimization results and discussion are shown in Section 4. The conclusions are summarized in Section 5.

\section{MATHEMATICAL DESIGN OF THREE-PHASE DRY-TYPE TRANSFORMERS}

The mathematical model of the three-phase dry-type transformer is obtained, and the boundary conditions of objective function have been determined according to reference (Tosun et al., 2012). Using these boundary conditions and objective functions, optimization will be performed according to current density $(s)$ and transformer iron cross-section acceptability $(C)$ values.

$$
\begin{gathered}
2.2<s<3.5\left(\mathrm{~A} / \mathrm{mm}^{2}\right) \\
5.9<C<10.6\left(\mathrm{~cm}^{2} \text { Joule }^{-1 / 2}\right)
\end{gathered}
$$

$S(\mathrm{kVA}), U_{1}$ and $I$ are parameters of the transformer, and they are the apparent power, excitation or winding voltage, and the current, respectively.

$S=\sqrt{3} U_{1} I$

$q_{f e}$ is the iron cross-section of the core, and $f$ is a fundamental frequency of the system.

$q_{f e}=C \sqrt{\frac{1000 S}{3 f}}$

The radius of the iron core $(D)$ is obtained as:

$D=\sqrt{\frac{4 q_{f e}}{(0.677) \pi}}$

Primary and secondary winding turn ratios are defined in Eq.4. Here $B$ is the magnetic flux density.

$N_{1}=\frac{U_{1}}{\sqrt{3} 4.44 f B q_{f e} 10^{-8}}$ 
$N_{2}=\frac{U_{2}}{\sqrt{3} 4.44 f B q_{f e^{10^{-8}}}}$

Cross-section of the transformer primary and secondary winding is obtained respectively:

$q_{1}=\frac{I_{1}}{s}$

$q_{2}=\frac{I_{2}}{S}$

$L_{s}$ is the height of windings, and $A_{s}$ is specific amper winding as $387 \mathrm{~A} / \mathrm{cm}$ for a $100 \mathrm{kVA}$ transformer given in (Aksu and Demirdelen, 2018):

$$
L_{s}=2 \frac{N_{1} I_{1}}{A_{s}}
$$

$a$ is a window width for the core type transformer and $k_{c u}$ is defined as a window copper fill factor.

$$
a=(0.04) \frac{N_{2} q_{2}}{(0.1) k_{c u} L_{S}}
$$

to obtain average winding lengths:

$$
\begin{aligned}
& L_{m_{1}}=\pi(D+3.32) \\
& L_{m_{2}}=\pi\left(10 D+8+a_{2}\right)
\end{aligned}
$$

After calculating winding lengths, winding resistances can be calculated, and $\rho_{0}=2.65 \times 10-8 \Omega \mathrm{m}$ denotes electric resistivity for aluminium.

$$
\begin{aligned}
& r_{1}=\rho_{0} \frac{L_{m_{1}} N_{1}}{q_{1}} \\
& r_{2}=\rho_{0} \frac{L_{m_{2}} N_{2}}{q_{2}}
\end{aligned}
$$

$r_{1}$ and $r_{2}$ are used to calculate winding losses:

$$
\begin{aligned}
& P_{c u 1}=3 I_{1}^{2} r_{1} \\
& P_{c u 2}=3 I_{2}^{2} r_{2} k
\end{aligned}
$$

Total winding losses can be given as below

$$
P_{c u}=P_{c u 1}+P_{c u 2}
$$

After determining the winding losses, the next step is calculating iron (core) losses. To obtain iron losses, weights of legs and yokes, specific yoke iron loss $\left(p_{f e j}\right)$ and specific leg iron loss $\left(p_{f e b}\right)$ must be calculated separately.

$p_{f e b}=p_{10} \xi_{2} B^{2}$ 
$p_{10}$ and $\xi_{2}$ are defined as the loss factor and the additional loss factor, respectively. The detailed definitions of these constants can be seen in (Aksu and Demirdelen, 2018). $\gamma_{F e}=7600 \mathrm{~kg} / \mathrm{m}^{3}$ is the ironspecific weight constant.

$G_{f e b}=3 \gamma_{F e} q_{f e} L_{s} 10^{-3}$

$G_{f e b}$ is the total weight of the transformer legs. The total iron losses for the legs can be obtained:

$P_{f e b}=G_{f e b} p_{f e b}$

$q_{f e j}$ is yoke cross-section area and it should be $20 \%$ more, therefore $q_{f e j}=1.2 q_{f e}$.

$G_{f e j}=3 \gamma_{F e j} q_{f e j} 2(2 M+0,8 D) 10^{-3}$

Here $M=0.851 D+0.1 L_{s} B_{j}$ is the yoke flux density, and it should be $20 \%$ less than flux density in the limbs. $B_{j}=\frac{B}{1.2}$.

$$
p_{f e j}=p_{10} \xi_{2} B_{j}^{2}
$$

Iron loss of yokes is shown in Eq. 22.

$P_{f e j}=G_{f e j} p_{f e j}$

Total iron losses of the transformer in terms of Watt is obtained:

$P_{f e}=P_{f e b}+P_{f e j}$

The total losses of the transformer are shown in Eq.24.

$$
P_{\text {total }}=P_{f e}+P_{c u}
$$

End of the calculations, the efficiency of the transformer can get as a percentage by $E q .25$. The main target of this paper is to maximize the efficiency of the transformer. Therefore, $E q .25$ is used as an objective function of three optimization methods for this study.

$$
\eta=\frac{S}{S+P_{\text {total }}}
$$

If we express the optimization parameters $x_{1}=s ; x_{2}=C ; x_{3}=\eta$ :

$$
X=\{2.2<s<3.5, \quad 5.9<C<10.6, \quad 0.9<\eta<1\}
$$

This study applies the optimization process by considering these limit values to a $100 \mathrm{kVA}$ transformer for validation. The optimized parameters have been used to redesign the transformer and seen the feasibility of the study. 
Table 2. General specifications and dimensions of three-phase dry-type transformer

\begin{tabular}{|l|l|}
\hline Quantity & \multicolumn{1}{|c|}{ Values } \\
\hline Power Level & $100 \mathrm{kVA}$ \\
\hline Voltages & $10 / 0.4 \mathrm{kV}$ \\
\hline Turns & $1819 / 42$ \\
\hline Window width & $245 \mathrm{~mm}$ \\
\hline Diameter of the iron core & $146 \mathrm{~mm}$ \\
\hline Primary winding length & $450 \mathrm{~mm}$ \\
\hline Secondary winding length & $490 \mathrm{~mm}$ \\
\hline Iron cross-section & $14740 \mathrm{~mm}^{2}$ \\
\hline Window length & $580 \mathrm{~mm}$ \\
\hline Core loss $\left(P_{\text {coreloss }}\right)$ & $400 \mathrm{~W}$ \\
\hline Copper losses $\left(P_{\text {cu }}\right)$ & $2000 \mathrm{~W}$ \\
\hline
\end{tabular}

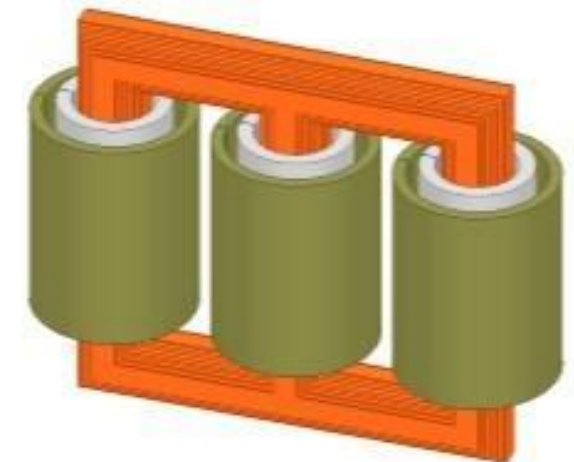

Figure 1. Transformer ANSYS/Maxwell model

\section{THE METHODOLOGY OF OPTIMIZATION TECHNIQUES}

\subsection{Simulated annealing}

The simulated annealing (SA) algorithm is a multi-dimensional optimization method inspired by the metallurgical annealing process. Providing the appropriate property changes with the solid-state temperature changes in metal materials with one or several connected processes. To avoid metastable states caused by blast cooling, metals are usually cooled rather slowly. Thus to metals, time is given to reach a stable, structurally robust, and low-energy level.

The same general process is used in the simulated annealing algorithm. Here the temperature value is assigned to a function, and optimization causes a temperature drop. Heat treatment (Simulated Annealing) (SA) is a random search algorithm developed by taking advantage of the analogy between cooling and freezing a metal to its minimum energy crystal structure and investigating the minimum in a more general system. This analogy forms the basis of a combinatorial optimization technique.

Simulated annealing was developed by Kirkpatrick et al. in 1983 to solve nonlinear problems (Kirkpatrick et al., 1983). It has attracted the attention of many researchers because of its simple application and wide application area (Bendaoud et al., 2019; Holzschuh et al., 2020). The most important advantage of the algorithm is that it can avoid getting stuck in local minimums over other methods.

The pseudocode that can be used to find the function minimum by simulated annealing is as follows.

1. Choose the initial value of $\mathrm{T}$.

2. Calculate $f\left(\overrightarrow{x_{l}}\right)$ for $x_{i}$

3. Calculate $f\left(\overrightarrow{x_{l}}\right)$ for $x_{i+1}$

4. if $f\left(\overrightarrow{x_{l+1}}\right)<f\left(\overrightarrow{x_{l}}\right)$, movement is accepted, otherwise;

a. Calculate the $\omega=\exp \left[\left(f\left(\overrightarrow{x_{l+1}}\right)-f\left(\overrightarrow{x_{l}}\right)\right) / T\right]$

b. $\quad$ random $r$ between $0<r<1$ 
c. if $\omega>r$ the solution is accepted, otherwise rejected

5. Calculate the new $x_{i+1}$.

6. Find the minimum fitness.

7. Decrease T

8. If the stop criteria is done, go to step 10

9. Go to step 2 and apply for a new $\mathrm{T}$

10. Finish

Where $\mathrm{T}$ is the temperature value, and $\mathrm{f}(\mathrm{x})$ is an objective function. $x_{i}$ and $x_{i+1}$ represent the solution candidate and the relationship between $x_{i}$ and $x_{i+1}$ like in Eq. 26:

$$
x_{i+1}=x_{i}+Q_{u}
$$

Where $Q_{u}$ is a matrix that controls the step size distribution.

\subsection{Particle swarm optimization}

The PSO, developed by Eberhart and Kennedy in 1995, is a population-based metaheuristic optimization technique (Eberhart and Kennedy, 1995). PSO, which birds inspire, is assumed that each particle can update its position and velocity by using global and local best values. Many researchers have applied PSO to their study because of its simple application (Latchoumi et al., 2019; Celtek et al., 2020). The position and velocity equations for a conventional PSO are as follows:

$$
\begin{aligned}
& v_{i}(t+1)=\omega v_{i}(t)+c_{1}\left(\operatorname{pbest}(t)-x_{i}(t)\right)+c_{2}\left(\operatorname{gbest}(t)-x_{i}(t)\right) \\
& x_{i}(t+1)=x_{i}(t)+v_{i}(t+1)
\end{aligned}
$$

Where pbest, gbest, $x_{i}(t), v_{i}(t+1)$ are the local best particle, the global best particle, the position of particle $i$ in iteration $t$, the velocity of particle $i$ in iteration $t+1$, respectively.

In $E q .27$ and 28, $t, v_{i}(t)$ and $x_{i}(t)$ indicate respectively the number of iterations, the speed of particle $\mathrm{i}$, and the position of particle $i$. The $c_{1}$ and $c_{2}$ are called acceleration coefficients where $0<c_{1}, c_{2} \leq 2$. The inertia weight $\omega \epsilon[0.8 ; 1.2]$ and $\omega$ set to 1 in the original PSO update speed equation. Inertia weight indicates how much of the previous speed is taken from the previous time step. Shortly, inertia weight was used to balance the global and local search capability of the PSO. Large inertia weight makes the global search easier, while small weight makes the local search easier. Inertia weight provides the balance between local and global search, and as a result, the optimal results are achieved with less iteration. Therefore, the determination of the appropriate value of inertia weight is very critical.

\subsection{Tree seed algorithm}

Tree Seed algorithm (TSA) is one of the heuristic algorithms developed inspired by nature. In this algorithm, the positions of trees and seeds in a certain area are considered as an optimization problem (Kiran, 2015). Each seed production is based on the best or randomly selected tree location in the tree population. The computational process starts by determining the starting positions of the trees using the following Eq.29;

$$
T_{i, j}=L_{j, \min }+\operatorname{rand}(0,1)\left(H_{j, \max }-L_{j, \min }\right)
$$


Where $i=1,2 \ldots, N$ and $j=1,2 \ldots, D, \mathrm{~N}$ is the tree number, $\mathrm{D}$ is the dimension. $T_{i, j}$ represents the position of the tree, $H_{\max }$ and $L_{\min }$ represent the top limit and bottom limit, respectively.

After the tree positions are generated, each location optimization problem is evaluated according to the objective function. Seed production is carried out in two different ways for each tree. This selection is determined by the most basic control parameter of the algorithm, defined as search tendency (ST). If the random value generated is lower than this parameter, Eq.30 is used, and if it is greater, the seed production mechanism is in $E q .31$ is used.

$$
\begin{gathered}
S_{i, j}=T_{i, j}+\operatorname{rand}(-1,1)\left(B_{j}-T_{r, j}\right) \\
S_{i, j}=T_{i, j}+\operatorname{rand}(-1,1)\left(T_{i, j}-T_{r, j}\right)
\end{gathered}
$$

Where $S_{i, j}$ is the jth dimension of the ith seed, $B_{j}$ is the jth dimension of the best tree, and $T_{r, j}$ is the jth dimension of the rth seed, which is random.

After the seeds produced are evaluated according to the purpose function, those with better suitability from the current tree position replace the trees in the next generation. The seed production and development process continues until the maximum number of fitness evaluations (FEs) is reached.

\section{RESULTS AND DISCUSSIONS}

In this study, we have aimed to design a $100 \mathrm{kVA}$ dry-type transformer in such a way that the efficiency is maximum. As it is suggested in the references that handle the efficiency issue, the core quality factor (C) and the current density (s), which are the basic design parameters, are selected as the optimization parameters (Celebi, 2008; Tosun et al., 2012; Aksu and Demirdelen, 2018). We formulated the efficiency as the objective function and updated the selected parameters to maximize it (Eq.25).

Other design parameters used in the transformer design are given in Table 3.

Table 3. Parameters used in transformer design (Aksu and Demirdelen, 2018)

\begin{tabular}{|c|c|c|}
\hline Symbols & Parameters & Value \\
\hline$p_{10}$ & Loss factor & 1.3 \\
\hline$\varepsilon_{2}$ & Additional loss factor & 1.15 \\
\hline $\mathrm{B}$ & Flux density & {$[1.5-1.7] \mathrm{T}$} \\
\hline$U_{1}$ & Primary winding voltage & $10000 \mathrm{~V}$ \\
\hline$U_{2}$ & Secondary winding voltage & $400 \mathrm{~V}$ \\
\hline$A_{s}$ & Specific ampere winding & $387 \mathrm{~A} / \mathrm{cm}$ \\
\hline
\end{tabular}

Losses are directly related to the type of transformer to be designed. In this study, the dry-type transformer has been optimized by PSO, TSA, and SA methods. It is aimed to obtain the maximum efficiency for each method. The calculation for each method was carried out in 50 iterations. Each calculation is obtained by running the algorithms 30 times because of the stochastic nature of the methods used in this study.

The results of optimization methods are given in Figures 2, 3, and 4. The horizontal axis and vertical axis represent the iteration number and objective function, respectively. The study aims to maximize efficiency while simultaneously obtaining the optimum $s$ and $C$ value of a three-phase dry-type transformer. Thus the objective functions show efficiency. Algorithms optimize the $\mathrm{C}$ and s parameters; thus, the transformer losses are minimized, and efficiency is maximized. The values used to plot the curves in three figures are the average values of the multiple runs ( 30 runs). 
Figure 2 shows the SA optimization results. As seen in Figure 2, the SA finds out the best value on the fourth iteration. The best value found out by SA is 0.981 . There is a slight fluctuation between iteration 5 and 50. We assume that it is because of the stochastic structure of the SA.

The result of the PSO technique is given in Figure 3. The best value, which is 0.9838 , is obtained on the fifth iteration. According to the results of the first iteration, the PSO gives better results than SA. The PSO starts the optimization process with 0.9822 , while SA begins with about 0.85 . These results show that the PSO method searches the solution space better than SA.

The results of TSA are given in Figure 4 . The best value obtained by TSA is 0.98439 , which is found in the third iteration. There is no fluctuation between the 3rd iteration and the 50th iteration. Therefore, it can be said that TSA generates very stable results. Therefore, the maximum efficiency of the transformer is obtained as $\eta=0.98439$ at $C=9.0196$ and $s=2.501$.

The maximum efficiencies obtained by SA, PSO, and TSA optimization algorithms are listed in Table 4. The transformer used as a prototype and the fem model given in Figure 1 above is expressed as Model in Table 4.

Time-dependent FEM analysis has been made with the basic design parameters of the transformer, and current-voltage graphs have been obtained, as seen in Figure 5. In addition, the iron and copper losses are shown separately in Figure 6. These values are the analysis results obtained with basic design parameters before the optimization.

After obtaining the optimum C and s values with SA, PSO, and TSA algorithms, transformer dimensions were changed using each method's optimum $C$ and s values. Therefore, six separate new simulations (three for core and three for copper losses) have been performed. Table 5 shows the new efficiency values obtained from the analysis of the three-phase dry-type transformer designed with the optimum $\mathrm{C}$ and s values calculated according to the optimization methods.

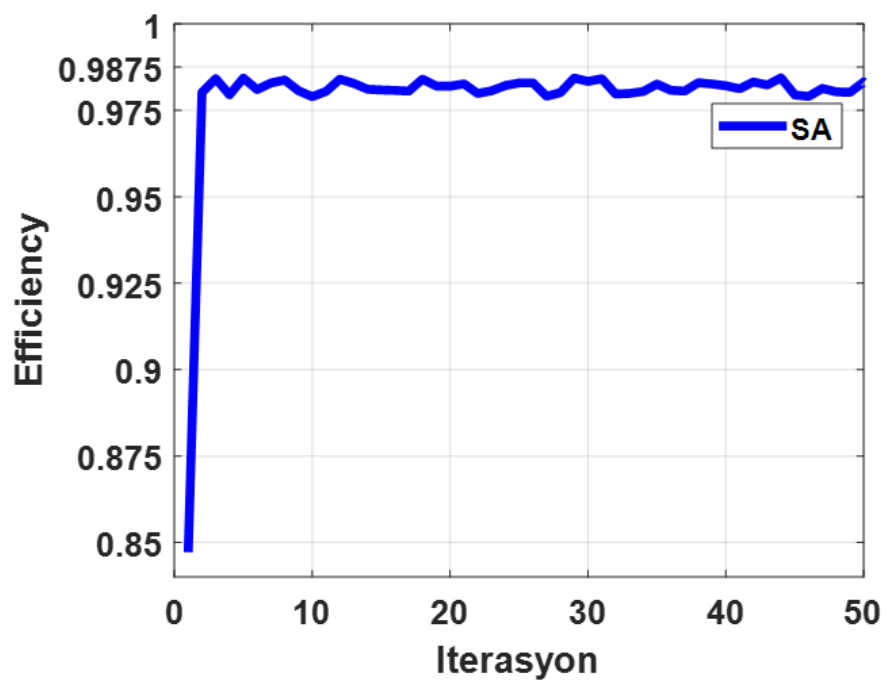

Figure 2. Change of objective function based on SA 


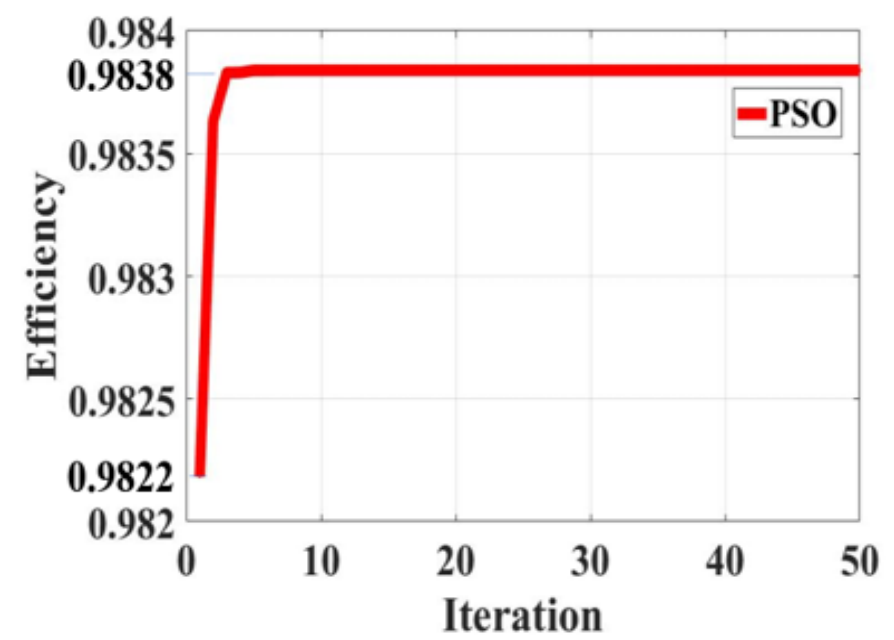

Figure 3. Change of objective function based on PSO

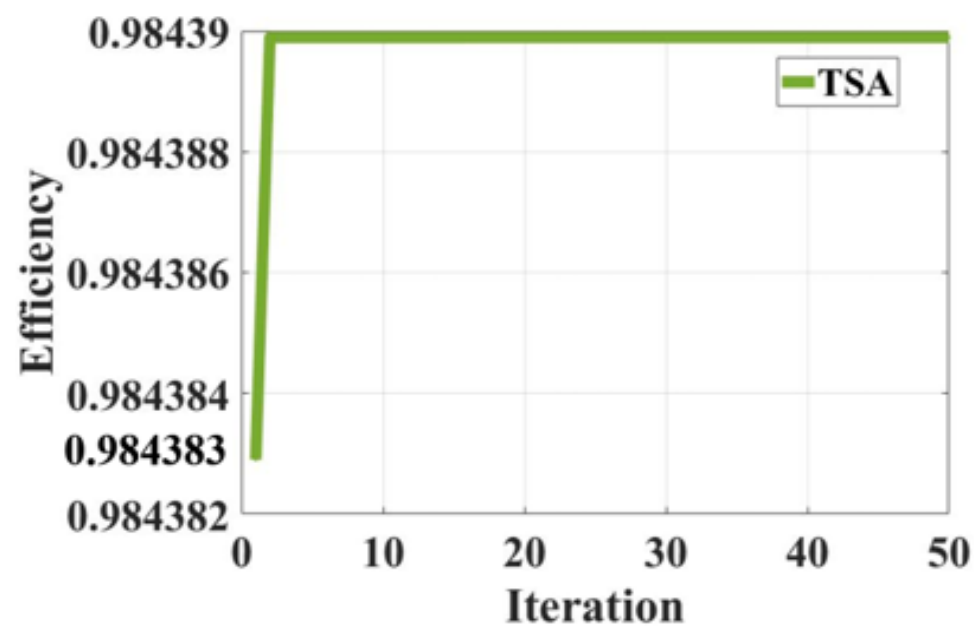

Figure 4. Change of objective function based on TSA

Table 4. Efficiency results of optimization techniques

\begin{tabular}{|c|c|}
\hline Algorithms & Efficiency \\
\hline Model & 0.9750 \\
\hline SA & 0.9810 \\
\hline PSO & 0.9838 \\
\hline TSA & 0.9844 \\
\hline
\end{tabular}




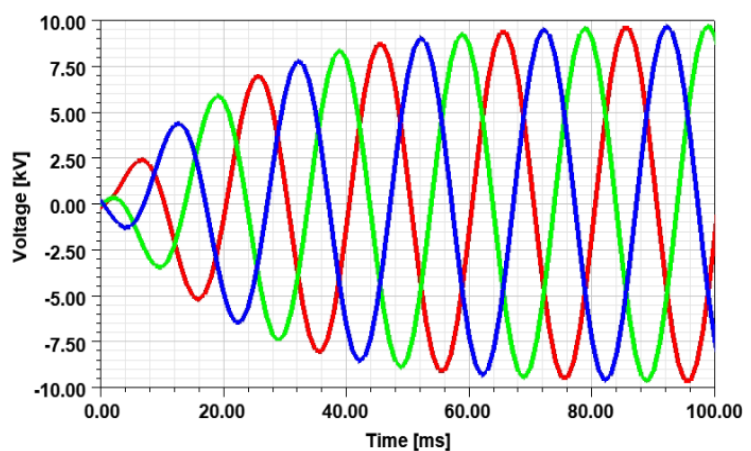

(a)

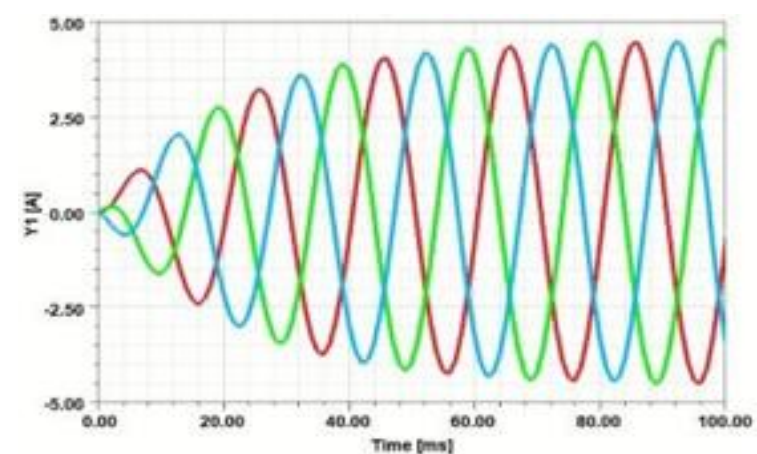

(b)

Figure 5. a) Excitation voltage b) Primary current

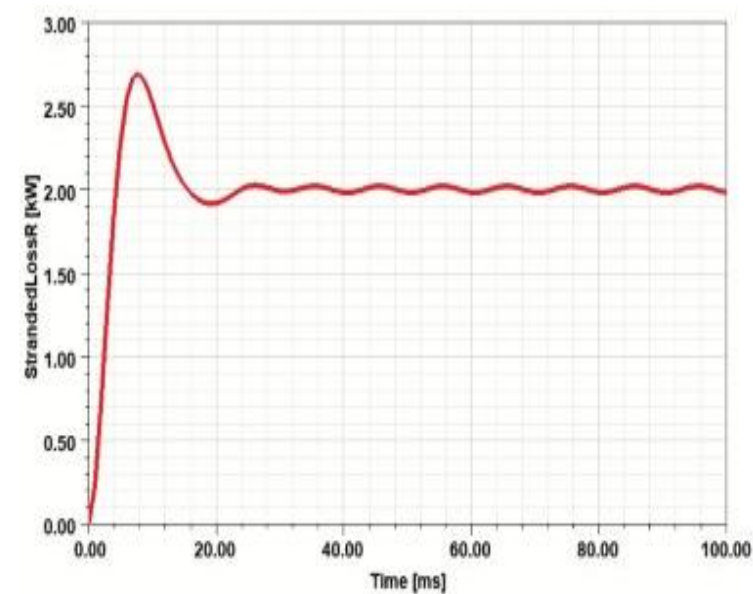

(a)

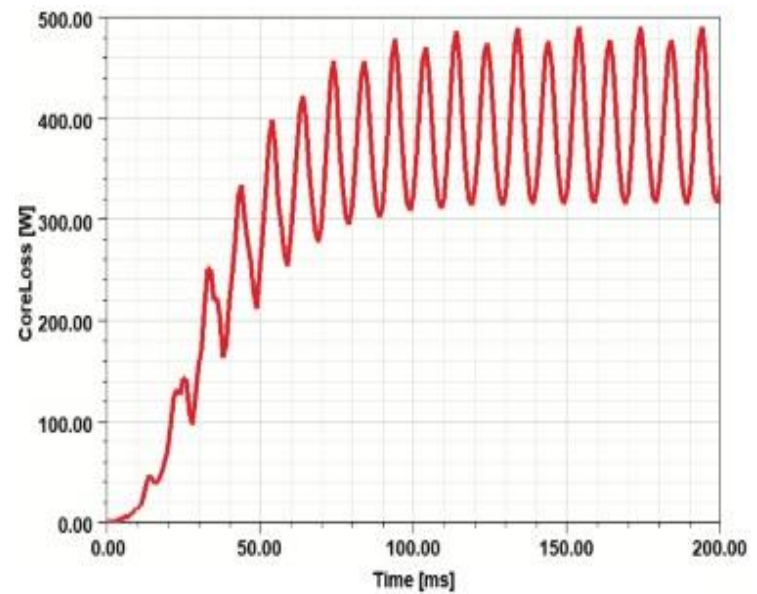

(b)

Figure 6. a) Winding Losses b) Core losses

Table 5. Efficiency result of FEM modeling with optimized parameters

\begin{tabular}{|l|c|}
\hline Algorithms & Efficiency \\
\hline Model & 0.9750 \\
\hline SA & 0.9800 \\
\hline PSO & 0.9803 \\
\hline TSA & 0.9815 \\
\hline
\end{tabular}

\section{CONCLUSIONS}

In this study, a three-phase $100 \mathrm{kVA}$ dry-type transformer was modeled and optimized to obtain maximum efficiency. Then the electromagnetic analyses are performed by using the ANSYS/Maxwell program. Moreover, the metaheuristic algorithms depending on the core coefficients $(C$ and $s)$ are used to obtain the highest transformer efficiency; the transformer is optimized by the SA, PSO, and TSA methods. The TSA is both the quickest and the best in finding the maximum efficiency among these three algorithms. The maximum efficiency of the transformer is obtained as $\eta=0.98439$ at $C=9.0196$ and $s=$ 2.501 parameter values. After optimization, the transformer design parameters are re-calculated using these optimized numbers. Maxwell analysis was performed, and optimization efficiency results and analysis results were compared to each other. The relative differences of these two efficiency results are approximately $0.38 \%, 0.29 \%$, and $0.1 \%$ for PSO, TSA, and SA, respectively. In conclusion, we have reached 
our goal of creating a guide for transformer manufacturers and designers on optimizing the design parameters for maximum efficiency in dry-type transformers.

\section{REFERENCES}

Aksu, İ. Ö. and Demirdelen, T., 2018, “A comprehensive study on dry type transformer design with swarm-based metaheuristic optimization methods for industrial applications", Energy Sources, Part A: Recovery, Utilization and Environmental Effects, 40(14), pp. 1743-1752. doi: 10.1080/15567036.2018.1486908.

Alyozbaky, O. S., Ab Kadir, M. Z. A., Izadi, M., Gomes, C., Azis, N. B., \& Isa, M. B. M. , 2019, “New Optimization Technique to Design the Core of Three-Phase Transformer", 2nd International Conference on Electrical, Communication, Computer, Power and Control Engineering, ICECCPCE 2019, pp. 13-18. doi: 10.1109/ICECCPCE46549.2019.203740.

Azizian, D., Bigdeli, M. and Faiz, J., 2016, “Design Optimization of Cast-Resin Transformer Using NatureInspired Algorithms", Arabian Journal for Science and Engineering, 41(9), pp. 3491-3500. doi: 10.1007/s13369-016-2066-x.

Basak, R., 2017, "Design of Single Phase Transformer Through Different Optimization Techniques", International Journal of Information and Communication Sciences, 2(3), p. 30. doi: 10.11648/j.ijics.20170203.11.

Bendaoud, R., Amiry, H., Benhmida, M., Zohal, B., Yadir, S., Bounouar, S., ... \& El Aydi, M., 2019, “New method for extracting physical parameters of PV generators combining an implemented genetic algorithm and the simulated annealing algorithm", Solar Energy, 194, pp. 239-247. doi: 10.1016/j.solener.2019.10.040.

Celtek, S. A., Durdu, A. and All, M. E. M., 2020, "Real-time traffic signal control with swarm optimization methods", Measurement: Journal of the International Measurement Confederation, 166. doi: 10.1016/j.measurement.2020.108206.

Cheema, M. A. M., Fletcher, J. E. and Dorrell, D., 2013, “A practical approach for the global optimization of electromagnetic design of 3-phase core-type distribution transformer allowing for capitalization of losses", IEEE Transactions on Magnetics, 49(5), pp. 2117-2120. doi: 10.1109/TMAG.2013.2242049.

Çelebi, M., 2008, “Genetik Algoritma ile Kuru bir Trafonun Maliyet Optimizasyonu. “ ELECO, Bursa, Turkey, 26-30.

Demirdelen, T., 2018, "A Heuristic Approach for Volume Calculation of Oil-Type Power Transformers : Firefly Algorithm", 7(4), pp. 41-46.

Demirdelen, T., 2019, “Optimal design and experimental validation long-lasting, low loss transformer for low power renewable energy system", Energy Sources, Part A: Recovery, Utilization and Environmental Effects, 41(20), pp. 2534-2548. doi: 10.1080/15567036.2019.1637973.

Eberhart, R. and Kennedy, J., 1995, "New optimizer using particle swarm theory", in Proceedings of the International Symposium on Micro Machine and Human Science, pp. 39-43. doi: 10.1109/mhs.1995.494215.

Esenboga, B. and Demirdelen, T., 2020, "Efficiency and Cost Based Multi-optimization and Thermal/Electromagnetic Analyses of 3-Phase Dry-Type Transformer", IETE Journal of Research. doi: 10.1080/03772063.2020.1732841.

Gaikwad, S., 2018, “Optimal Placement and Sizing of Distribution Transformers of Existing Network using Genetic Algorithm and Simulated Annealing", Asian Journal for Convergence in Technology (Ajct)Ugc Listed, 4(1). Available at: www.asianssr.org.

Holzschuh, B., Lahner, Z. and Cremers, D., 2020, "Simulated Annealing for 3D Shape Correspondence", Proceedings - 2020 International Conference on 3D Vision, 3DV 2020, pp. 252-260. doi: 10.1109/3DV50981.2020.00035.

Kiran, M. S., 2015, “TSA: Tree-seed algorithm for continuous optimization", Expert Systems with Applications, 42(19), pp. 6686-6698. doi: 10.1016/j.eswa.2015.04.055. 
Kirkpatrick, S., Gelatt, C. D. and Vecchi, M. P. ,1983, “Optimization by simulated annealing”, Science, 220(4598), pp. 671-680. doi: 10.1126/science.220.4598.671.

Latchoumi, T. P., Balamurugan, K., Dinesh, K., \& Ezhilarasi, T. P., 2019, "Particle Swarm Optimization approach for waterjet cavitation peening", Measurement: Journal of the International Measurement Confederation, 141, pp. 184-189. doi: 10.1016/j.measurement.2019.04.040.

Orosz, T., Borbély, B. and Tamus, Z. Á., 2017, “Performance comparison of multi design method and metaheuristic methods for optimal preliminary design of core-form power transformers", Periodica polytechnica Electrical engineering and computer science, 61(1), pp. 69-76. doi: 10.3311/PPee.10207.

Orosz, T., Pánek, D. and Karban, P., 2020, “FEM based preliminary design optimization in case of large power transformers", Applied Sciences (Switzerland), 10(4). doi: 10.3390/app10041361.

Patil, R. and Kushare, B. E., 2016, “Design and optimization of inter-coil insulation system of a Cast resin transformer using FEM", in International Conference on Electrical, Electronics, and Optimization Techniques, ICEEOT 2016, pp. 2887-2890. doi: 10.1109/ICEEOT.2016.7755225.

Rodríguez, S., Sánchez, N., \& Gómez, D., 2019, “Optimization of geometric parameters of power transformer using bee"s algorithm", Annals of Electrical and Electronic Engineering, 2(7), pp. 7-10. doi: 10.21833/aeee.2019.07.002.

Smolka, J. and Nowak, A. J., 2011, “Shape optimization of coils and cooling ducts in dry-type transformers using computational fluid dynamics and genetic algorithm", IEEE Transactions on Magnetics, 47(6 PART 2), pp. 1726-1731. doi: 10.1109/TMAG.2011.2109731.

Soldoozy, A., Esmaeli, A., Akbari, H., \& Mazloom, S. Z., 2018, “Implementation of tree pruning method for power transformer design optimization", International Transactions on Electrical Energy Systems, (May), pp. 1-19. doi: 10.1002/etep.2659.

Tosun, S., Öztürk A., Demir H., Kuru L., 2012, Kuru Tip Transformatörün Tabu Arama Algoritmasi Yöntemi İle Ağırlık Optimizasyonu, Journal of Advanced Technology Sciences.

Wang, T., Liu, J., Wang, Y., \& Hui, L., 2020, “Optimization of Structural Parameters for a New-Type Magnetic Integration Structure CRT Considering Loss and Cost", IEEE Access, 8, pp. 6852568532. doi: 10.1109/ACCESS.2020.2984545.

Zhang, M., Wang, N. and Ding, X., 2013, “Improved artificial fish swarm algorithm for fault diagnosis of dry-type transformer", in Proceedings - 2013 4th International Conference on Digital Manufacturing and Automation, ICDMA 2013, pp. 679-683. doi: 10.1109/ICDMA.2013.161. 